\title{
NORDINA: CHANGING EDITORS
}

Since 2004, we have had an exiting time as editors in building up and maintaining NorDiNa. The need for a Nordic journal in science education was evident at that time, but still it was not clear how the journal would be received by the research community. Would people read it? Would they send us manuscripts? Would we manage to keep to desired standards? After 6 years, we are proud to be able to answer these questions with "YES". The journal is well established, people keep sending us manuscripts and they are often referred to elsewhere. Our "baby" is about growing up. However, any journal as well as editors need to renew themselves; we have therefore decided to retire as editors for NorDiNa. However, the "child" is in very good hands since Christina Ottander (University of Umeå) and Sonja M. Mork (The Norwegian Centre for Science Education, Oslo) will be the new editors. They have started the work with great enthusiasm. Professor Svein Sjøberg, University of Oslo, will replace Professor Björn Andersson as Senior Advisor.

During the 6 years we have put a lot of work into NorDiNa. The successful result has, however, been dependent on several other individuals. We warmly thank Björn Andersson for always being ready to help and for his kind and thoughtful advice when the editors have been facing complicated matters. With the support from Anders Isnes at the Norwegian Centre for Science Education, we have never had to worry about financial issues or formal technicalities of the journal, and his co-worker Lise Faafeng has always done the rather cumbersome layout work with great patience, even when authors as well as editors have required last minute changes. The quality of published articles has been ensured by thoughtful reviews by more than a hundred different referees in the Nordic countries and elsewhere. We warmly thank them for their effort and their invisible, but important, contribution to our journal. Specifically, we wish to thank the following colleagues for having acted as referees for NorDiNa in 2009 and 2010:

Mikael Alexandersson
Björn Andersson
Carl Angell
Frank Bach
Sylvia Benckert
Jonte Bernhard

Mikael Alexandersson

Björn Andersson

Carl Angell

Sylvia Benckert

Jonte Bernhard

\author{
Jenny Byrne \\ Jens Dolin \\ Sibel Erduran \\ Bob Evans \\ Niklas Gericke \\ Marcus Hammann
}


Ellen Henriksen

Johan Häggström

Kalle Juuti

Per Morten Kind

Tom Klepaker

Erik Knain

Christina Kärrqvist

Cedric Linder

Mattias Lundin

Lena Löfgren

Allyson Macdonald
Ola Magntorn

Sonja Mork

Eva Nyberg

Clas Olander

Rolf V. Olsen

Irmeli Palmberg

Michael Reiss

Phil Scott

Ann Zetterqvist

Marianne Ødegaard

Finally, we wish Christina and Sonja good luck as new editors and the rest of you good luck in writing new articles for NorDiNa!

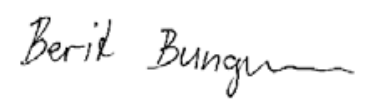

Berit Bungum

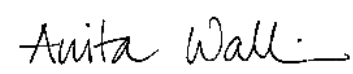

Anita Wallin 